Primljen / Received: 23.10.2012. Ispravljen / Corrected: 18.1.2013.

Prihvaćen / Accepted: 25.1.2013.

Dostupno online / Available online: 15.2.2013.

\section{Numerical modelling of in-plane creep behaviour of reinforced and prestressed concrete structures}

Authors:

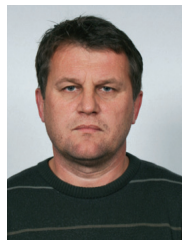

Asst.Prof. Mladen Kožul, PhD. CE

University of Mostar

Faculty of Civil Engineering

mladen.kozul@tel.net.ba

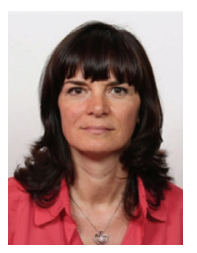

Prof. Željana Nikolić, PhD. CE

University of Split

Faculty of Civil Engineering, Arch. and Geodesy

zeljana.nikolic@gradst.hr

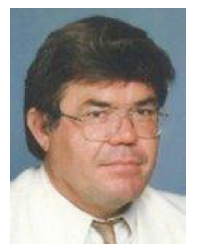

Prof. Ante Mihanović, PhD. CE

University of Split

Faculty of Civil Engineering, Arch. and Geodesy ante.mihanovic@gradst.hr
Preliminary note

\section{Mladen Kožul, Željana Nikolić, Ante Mihanović}

\section{Numerical modelling of in-plane creep behaviour of reinforced and prestressed concrete structures}

The numerical model for the analysis of in-plane creep behaviour of concrete, based on the correction of the modulus of elasticity in principal direction, for the current state of principal stresses, is presented. The elastic modulus correction is dependent on the current creep coefficient and the current elastic modulus as obtained from the uniaxial diagram of concrete in compression. The model's accuracy was analyzed on appropriate laboratory and numerical examples of reinforced and prestressed concrete structures, using a computer program developed for that purpose.

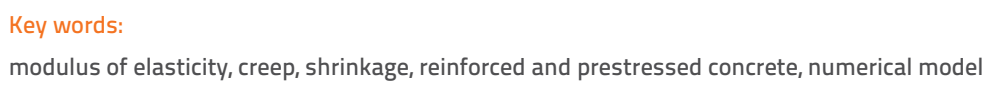

Prethodno priopćenje

\section{Numerički model puzanja armiranih i prednapetih betonskih konstrukcija u ravnini}

Prikazan je numerički model za analizu deformacija puzanja betona u ravnini, utemeljen na korekciji modula elastičnosti u glavnim pravcima, za trenutno stanje glavnih naprezanja. Korekcija modula elastičnosti ovisi o trenutnom koeficijentu puzanja i trenutnom modulu elastičnosti dobivenom iz jednoosnog radnog dijagrama betona u tlaku. Na temelju izrađenog računalnog programa izvršena je analiza točnosti modela na odgovarajućim primjerima laboratorijski i numerički ispitivanih armiranih i prednapetih betonskih konstrukcija.

Ključne riječi:

modul elastičnosti, puzanje, skupljanje, armirani i prednapeti beton, numerički model

Vorherige Mitteilung

Mladen Kožul, Željana Nikolić, Ante Mihanović

\section{Numerisches Model des Kriechverhaltens von Stahl- und Spannbetonkonstruktionen in der Ebene}

In der vorliegenden Arbeit ist ein numerisches Modell für die Analyse der Kriechverformung von Beton in der Ebene dargestellt, das sich auf der Korrektur des Elastizitätsmoduls für die den Hauptspannungen im aktuellen Spannungszustand entsprechenden Richtungen basiert. Die Berichtigung des Elastizitätsmoduls erfolgt in Abhängigkeit von den momentanen Werten des Kriechkoeffizienten und des auf dem Arbeitsdiagramm des Betons unter einachsiger Druckbeanspruchung beruhendem Elastizitätsmoduls. Mit Hilfe eines entwickelten Computerprogramms ist eine Analyse der Genauigkeit des Modells für entsprechende Beispiele experimentell und numerisch untersuchter Stahl- und Spannbetonkonstruktionen vorgenommen worden. 


\section{Introduction}

The analysis of time-dependent deformations of concrete, such as creep and shrinkage, necessarily requires monitoring of concrete deformations over time, and the study of influence these deformations exert on the reinforcement and prestressing steel. This influence is primarily reflected in the increase of deformation and stress redistribution, and in concrete cracking. Because of the problem of durability and, in some cases, of stability of concrete structures, a realistic estimation of these deformations is very important [1-5].

The creep of concrete belongs to viscous deformations that develop over time and are mainly described through empirical expressions, the results of which should correspond to the actual measured creep deformation of concrete. It occurs in the compression zone, and also in the tensile zone of concrete. Since the tensile strength of concrete is significantly lower than the compressive strength, the tensile creep is not so significant. It is known that the final or permanent deformation can be two or more times greater than the current elastic deformation of reinforced and prestressed concrete structures. This is important not only for the in-service behaviour of structures, but also for the redistribution of stresses and unforeseen occurrence of cracks in concrete. The analysis of reinforced and prestressed concrete structures, especially ones with larger spans and heights, is nowadays not considered complete without inclusion of time-dependent deformations of concrete.

There are many models of concrete creep, but most of them are based on empirical expressions that define certain parameters influencing creep deformation of concrete [1-4]. Such models are calibrated to the experimental analysis of this problem. Since experimental models are generally simple, mapping results on a complex real structure is not always appropriate. Because of obvious complexity of the problem in practice, we tend to use simpler models that are sufficiently accurate and simple for engineering applications.

In this paper, the existing software package PRECON [6-8] was used as a background for analysing creep deformations of concrete. The software can be used to analyse reinforced and prestressed concrete structures in case of the in-plane state of stress / strain and axially symmetric state for the quasistatic loading. This model includes all essential nonlinear effects of the concrete, reinforcement and prestressing tendons. Based on this model, an appropriate program for analysing time-dependent deformations of concrete was developed [9]. The shrinkage model for concrete is taken from ENV 206 [10], while a new numerical procedure, incorporated into the existing model, is developed for the analysis of creep deformations. This new numerical procedure is based on the adjustment of the stiffness matrix of concrete at each Gauss point over time, while the choice is left open for an appropriate creep coefficient and uniaxial concrete compression relationship [9].

\section{Nonlinear model for post tensioned concrete structures}

The model of nonlinear behaviour of post tensioned plane concrete structures is taken from [6]. An ideal relationship between the concrete, reinforcement and prestressing tendons is implied. Concrete structures are discredited using standard 2D 8-node isoparimetric finite elements. Reinforcement and prestressed tendons are modeled with 1D 3-nodal isoparametric finite elements that can be set independently of the $2 \mathrm{D}$ mesh of finite elements.

The model provides description of linear and curved tendons. To ensure continuity, the end node of the $1 \mathrm{D}$ tendon element must be located at the intersection with the edges of twodimensional elements of concrete, while the coordinates of the middle node are determined with an iterative interpolation procedure. A brief description of the material model is given below, while a more detailed description can be found in [6-9].

\subsection{Material models}

\subsubsection{Concrete}

The theory of elasto-viscoplasticity is used to describe the behaviour of concrete in compression [11]. Yield criterion is defined through the first two invariants of stress tensor. After the stress reaches the surface flow, the region of plastic deformation follows, and it is characterized by the laws of yielding and hardening. The associated law on concrete flow in compression is adopted [11-14]. The crushing or collapse of concrete is defined by limit strains. Because of the lack of experimental data related to limit deformations of concrete, the deformation condition of crushing is formulated similarly with the Von Misses yield criterion, where stresses are replaced with deformations. The behaviour of concrete in tension is linearly elastic until the tensile strength is reached, when the tensile softening model is adopted $[6,9,11]$ with linear decrease of stress perpendicular to the direction of crack, and the process of loading and unloading. The smeared crack model is used to describe the opening and closing of cracks.

Shear stiffness of cracked concrete is modeled through reduction of the shear modulus $[6,11,14]$.

\subsubsection{Reinforcement and prestressing steel}

The reinforcement and prestressing steel assume axial stresses only, and are therefore modeled with the onedimensional elasto-viscoplastic model [6-8], which includes a possible hardening and elastic unloading. 


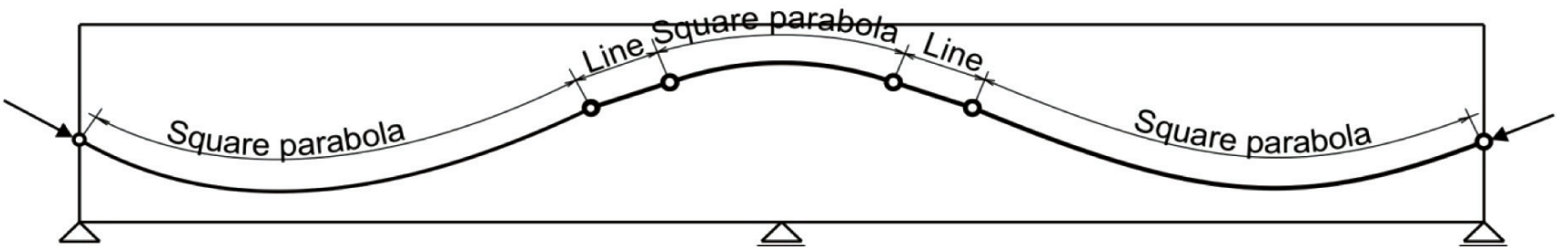

Figure 1. Possible cable positions [7]

\subsection{Numerical modelling of reinforcement and prestressed tendons}

The analysis of prestressed and reinforced concrete structures requires definition of the behaviour of concrete, rebars, tendons, and their joint action. Prestressed tendons and traditional reinforcement are modelled with 1D 3-nodal isoparametric finite elements, which are incorporated into $2 \mathrm{D}$ concrete finite elements [6-8]. The choice of finite element mesh of concrete structure is independent of the geometry and position of the reinforcement and tendons. The position of tendons is specified by nodes whose coordinates are defined in the global coordinate system. The model provides a description of linear and curved tendons (Figure 1).

The prestressing force, which occurs in the cable, is transferred to the nodes of $2 \mathrm{D}$ concrete elements in form of equivalent nodal forces [6-8].

\section{Numerical model of concrete creep}

\subsection{Introduction}

In this section, a brief description is given of a numerical model based on correction of the current elastic modulus of concrete, in the principal stress directions, and also as a function of the creep coefficient of concrete. The creep function, and the creep coefficient of concrete, was taken from EC2 [10], and are defined by the following equations:

$J\left(t, t_{0}\right)=\frac{1}{E_{c}\left(t_{0}\right)}+\frac{\phi\left(t, t_{0}\right)}{E_{c 28}}$

$\phi\left(t, t_{0}\right)=\phi_{0} \beta_{c}\left(t-t_{0}\right)$

where:

$J\left(t, t_{0}\right) \quad$ - creep function in time $t$

$\phi\left(t, t_{0}\right)$ - creep coefficient

$E_{c}\left(t_{0}\right)$ - tangent modulus of elasticity of concrete in time $t_{0}$

$E_{c 28}$ - tangent modulus of elasticity of concrete at 28 days

$\phi_{0}=\phi_{R H} \beta\left(f_{c m}\right) \beta\left(t_{0}\right) \quad$ - basic creep coefficient

$\beta_{c}\left(t-t_{0}\right)=\left[\frac{t-t_{0}}{\beta_{H}+\left(t-t_{0}\right)}\right]^{0.30} \begin{aligned} & \text { - coefficient that describes development } \\ & \text { of creep deformation over time. }\end{aligned}$

If stresses in concrete do not significantly vary, the expression for the effective modulus of elasticity can be used to determine creep deformation:

$$
E_{c, \text { eff }}=\frac{E_{c m}\left(t_{0}\right)}{1+\phi\left(t, t_{0}\right)}
$$

The current elasticity modulus of concrete, $f$, is determined through the working diagram of concrete, for the corresponding principal stress values at some point in time. For a given load level, the principal stress in all Gauss points of construction is known at the initial moment of time $t_{0}$. Using these stresses and adopted working diagram of concrete, the current secant elastic modules can be determined for each main direction (Figure 2). Then, the current elasticity module is corrected via an appropriate concrete creep coefficient, using the expression (3) for the effective modulus of elasticity of concrete. In this way, a local orthotropy of concrete is introduced at the level
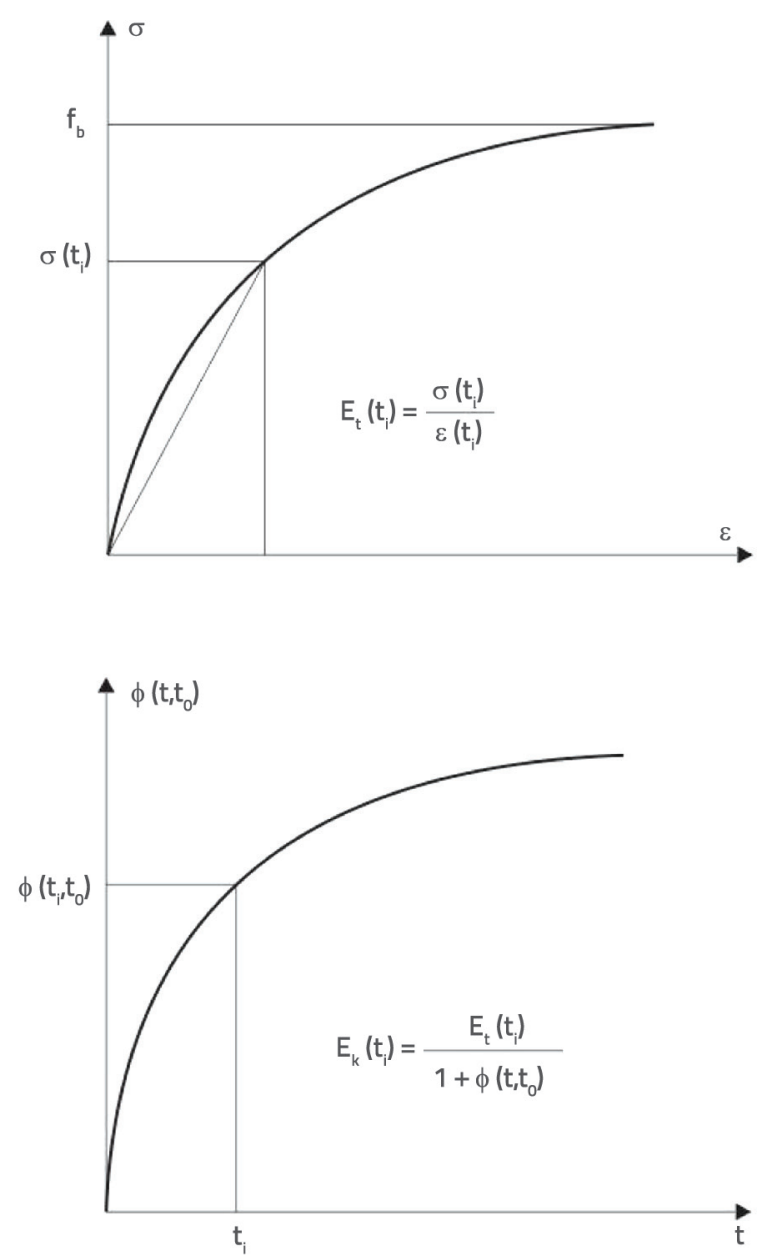

Figure 2. Correction of the elastic modulus of concrete 
of the corresponding areas of each integration point, which is then reflected on the material matrix, and finally on the finite element stiffness matrix of concrete. In this way, the character of principal stresses is taken into account.

\subsection{Correction of elastic modulus of concrete}

In the formulation of this model, the current modulus of elasticity of concrete $E(t)$ directions of principal compressive stress of each integration point. Therefore, the Hogenstad's working diagram of concrete in compression [15], is adopted, as shown in Figure 3.

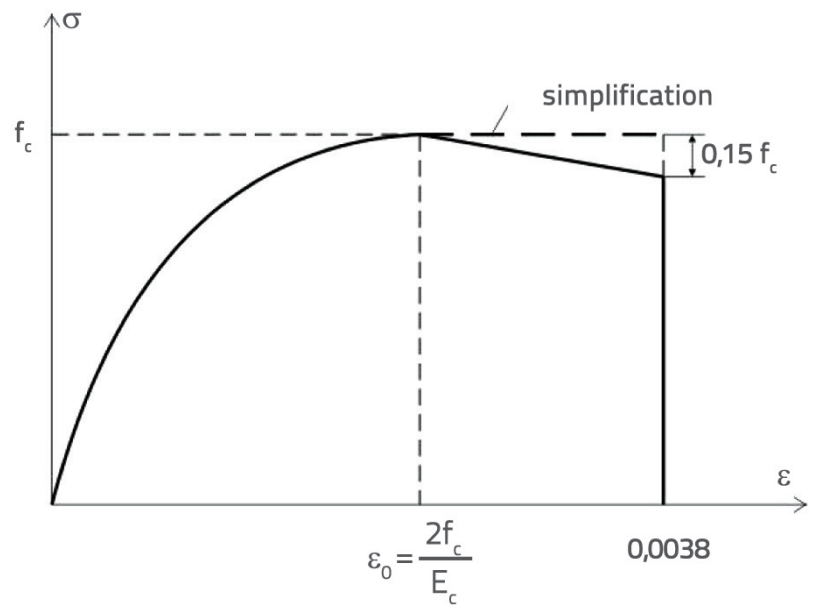

Figure 3. Working diagram according to Hogenstad [15]

Using the relationship between the current principal stress in a given direction and the corresponding current strain obtained from the working diagram of concrete, the current secant modulus of elasticity of concrete in that principal direction can be obtained.

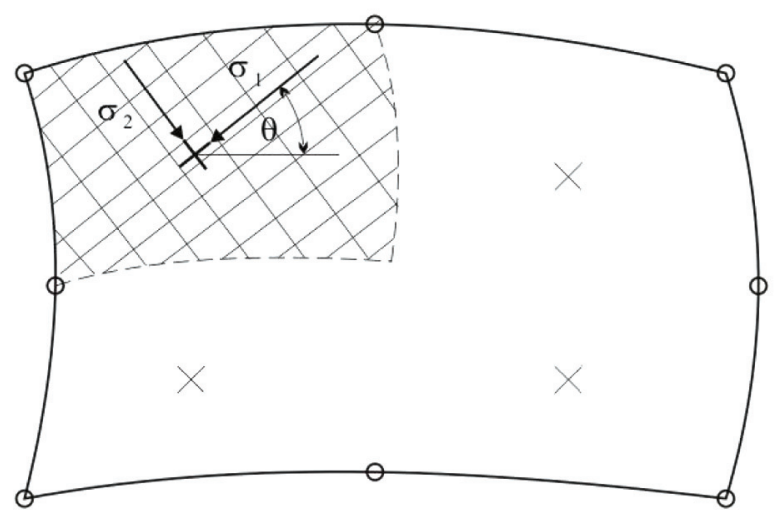

Figure 4. Principal stresses in Gauss point (orthotropy)

If it is assumed that the trends and directions of principal stresses $\sigma_{1}$ and $\sigma_{2}$ for the final external load are as shown in Figure 4., and if current deformations $\varepsilon_{1}$ and $\varepsilon_{2}$ are determined from the working diagram of concrete, then the current modulus of elasticity of concrete can be determined for each
Gauss point, and for each principal direction, according to the following expressions:

$$
\begin{gathered}
E_{1}\left(t_{0}\right)=\frac{\sigma_{1}\left(t_{0}\right)}{\varepsilon_{1}\left(t_{0}\right)}, \quad E_{2}\left(t_{0}\right)=\frac{\sigma_{2}\left(t_{0}\right)}{\varepsilon_{2}\left(t_{0}\right)} ; \\
E_{1}\left(t_{1}\right)=\frac{\sigma_{1}\left(t_{1}\right)}{\varepsilon_{1}\left(t_{1}\right)}, \quad E_{2}\left(t_{1}\right)=\frac{\sigma_{2}\left(t_{1}\right)}{\varepsilon_{2}\left(t_{1}\right)} ; \\
\vdots \\
E_{1}\left(t_{n}\right)=\frac{\sigma_{1}\left(t_{n}\right)}{\varepsilon_{1}\left(t_{n}\right)}, \quad E_{2}\left(t_{n}\right)=\frac{\sigma_{2}\left(t_{n}\right)}{\varepsilon_{2}\left(t_{n}\right)} .
\end{gathered}
$$

Principal stresses $\sigma_{1,2}\left(t_{0}\right), \sigma s_{1,2}\left(t_{1}\right), \ldots \sigma_{1,2}\left(t_{n}\right)$ at any time point $t_{i}$ are obtained from the numerical analysis.

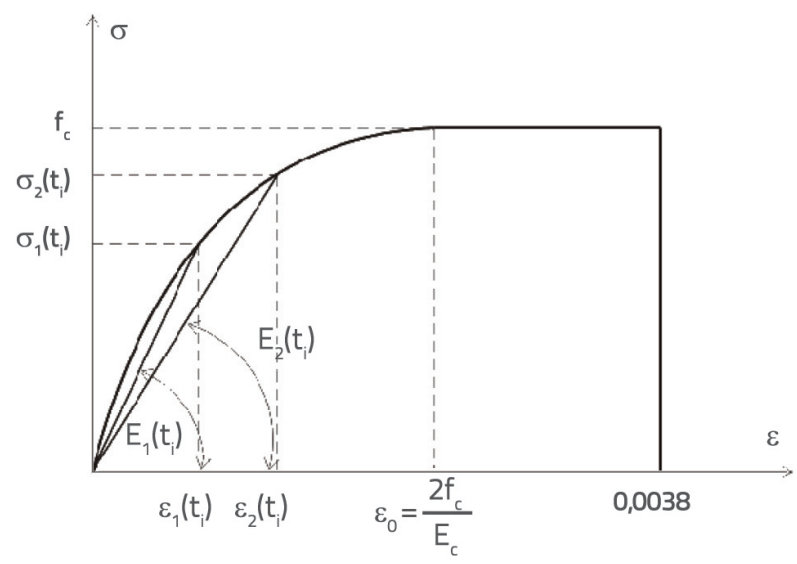

Figure 5. Current secant modulus of elasticity in principal directions

The current modulus of elasticity of concrete in the direction of main compressive stresses shall be adjusted to enable numeric simulation of the creep deformation of concrete. In this way, a fictitious orthotropic material is introduced at each Gauss point where at least one principal stress is compressive. No correction of modulus is made in the direction of the principal tensile stress, and so the modulus is equal to the initial elastic modulus in these directions, if there are no cracks in the concrete. The corrections are made once the current modulus of elasticity of concrete is established according to expression (4). For each principal direction, the expression (3) can be written as follows:

$E^{k}(t)=\frac{E^{t}(t)}{1+\phi\left(t, t_{0}\right)}=E^{t}(t) \cdot B(t)$

where $E^{k}(t)$ is the corrected modulus of elasticity of concrete at some point in time, for some principal direction, and $E^{t}(t)$ is the current modulus of elasticity of concrete for the same direction. The time function $B(t)=\frac{1}{1+\phi\left(t, t_{0}\right)}$ depends on the creep coefficient, and it is the same for each principal direction within a given time. This assumption is reasonable, although there is a choice of different time functions for specific stresses.

The corrected modulus of elasticity of concrete is then entered into the material matrix, which assumes the following form for the plane stress state and the time point $t_{i}$ : 
$D_{\text {ort }}\left(t_{i}\right)=\left[\begin{array}{ccc}\frac{E_{1}^{k}\left(t_{i}\right)}{c} & \frac{v_{12} E_{2}^{k}\left(t_{i}\right)}{c} & 0 \\ \frac{v_{21} E_{2}^{k}\left(t_{i}\right)}{c} & \frac{E_{2}^{k}\left(t_{i}\right)}{c} & 0 \\ 0 & 0 & G_{12}\end{array}\right]$

The above orthotropic matrix should be transformed from the material to global axes, and orthotropic material matrix in the global coordinates has the form:

$\mathrm{D}=\mathrm{TD}_{\text {ort }} \mathrm{T}^{\top}$

where $\mathbf{T}$ is the transformation matrix.

This matrix is used to form the finite element stiffness matrix and it is valid only in the area that belongs to a particular Gauss point where both principal stresses are compressive, or one principal stress is compressive while the other is tensile. In case both principal stresses in the Gauss point are tensile, then the isotropic material matrix should be used in this region, or the matrix of cracked concrete if there are cracks in the concrete. In this case, the modulus of elasticity of concrete is equal to the initial modulus of elasticity, or it is reduced according to the adopted model for tensile softening $[6,7,11]$. The Poisson's ratios for the orthotropic case can be written as follows [16]:

$v_{12}=-\frac{\varepsilon_{2}}{\varepsilon_{1}}, \quad v_{21}=-\frac{\varepsilon_{1}}{\varepsilon_{2}}$

The material matrix (6) is a function of five material parameters, but only four of them are independent. This conclusion is based on the fact that the material matrix has to be symmetric, which means that the following equality holds:

$\frac{v_{21}}{E_{2}}=\frac{v_{12}}{E_{1}}$

Several expressions for shear modulus $G$ of orthotropic material have been proposed. Here, we have used the expression which takes the mean value of $E_{1}$ and $E_{2}$ and also $v_{1}$ i $v_{2}[16]$ :

$G_{12}=\frac{E_{1}+E_{2}}{4\left[1+\frac{1}{2}\left(v_{1}+v_{2}\right)\right]}$

The finite element stiffness matrix of concrete is of standard form:

$k_{e}=\int_{V_{e}} B^{T} D B d V_{e}$,

where, for the corresponding orthotropic areas of individual integration points, the material matrix $\mathbf{D}$ is given by expression (7).

After formation of the stiffness matrix, the standard procedure is used to form equilibrium equations and solve them by incremental-iterative procedure using the finite element method.

\section{Numerical procedure}

The nonlinear procedure for the analysis of stresses and deformations is divided into four phases so as to enable an accurate numerical description of the real behaviour of plane reinforced and prestressed concrete structures.

\section{Phase I}

In this phase the structure is calculated for the load that exists prior to the prestressing of tendons (self-weight, and part of the dead load). The structure consists of the concrete and traditional reinforcement.

\section{Phase II}

In this phase tendons are prestressed separately, and the prestressing force can be applied at once or incrementally, so that the gradual prestressing process can be simulated. Upon tensioning, the tendon is not treated as a structural element, i.e. only its geometry is used in order to obtain the initial influence in form of the equivalent prestressing load. When the next tendons are prestressed, the previously prestressed tendons function as a traditional reinforcement with the given initial stress.

\section{Phase III}

After all tendons have been prestressed, the structure assumes an extra load (remaining dead load and live load). The stiffness of the structure is now engaged, with concrete, reinforcement and all prestressed tendons. The load can now be applied incrementally until failure.

\section{Phase IV}

When all loads are applied and nonlinear structural analysis is completed, the numerical procedure continues with the fourth phase in which the deformation analysis of creep and shrinkage of concrete is performed. Shrinkage deformations are included in the model EC2 [10], while the creep deformation are analysed using the previously described model. In this way, it is possible to determine, at any given time, the deformations and their impact on concrete, rebars, prestressed tendons, and the structure as a whole.

\section{Numerical examples}

\section{Example 1.}

In this example, the analysis of the reinforced concrete beam type C3 is performed, as experimentally tested in [17]. The beam geometry and loading are shown in Figure 6. The experiment monitored displacements in the middle of the span, and the deformations state at designated measurement points over two years. During this period, the beam was kept at constant relative humidity of $50 \%$, and at constant ambient temperature of $21^{\circ} \mathrm{C}$. Material parameters for the short-term and long-term load are given in Tables 1 and 2. The beam is discretized with 18 eight-node isoparametric $2 \mathrm{D}$ elements, while the height is divided into two elements. 


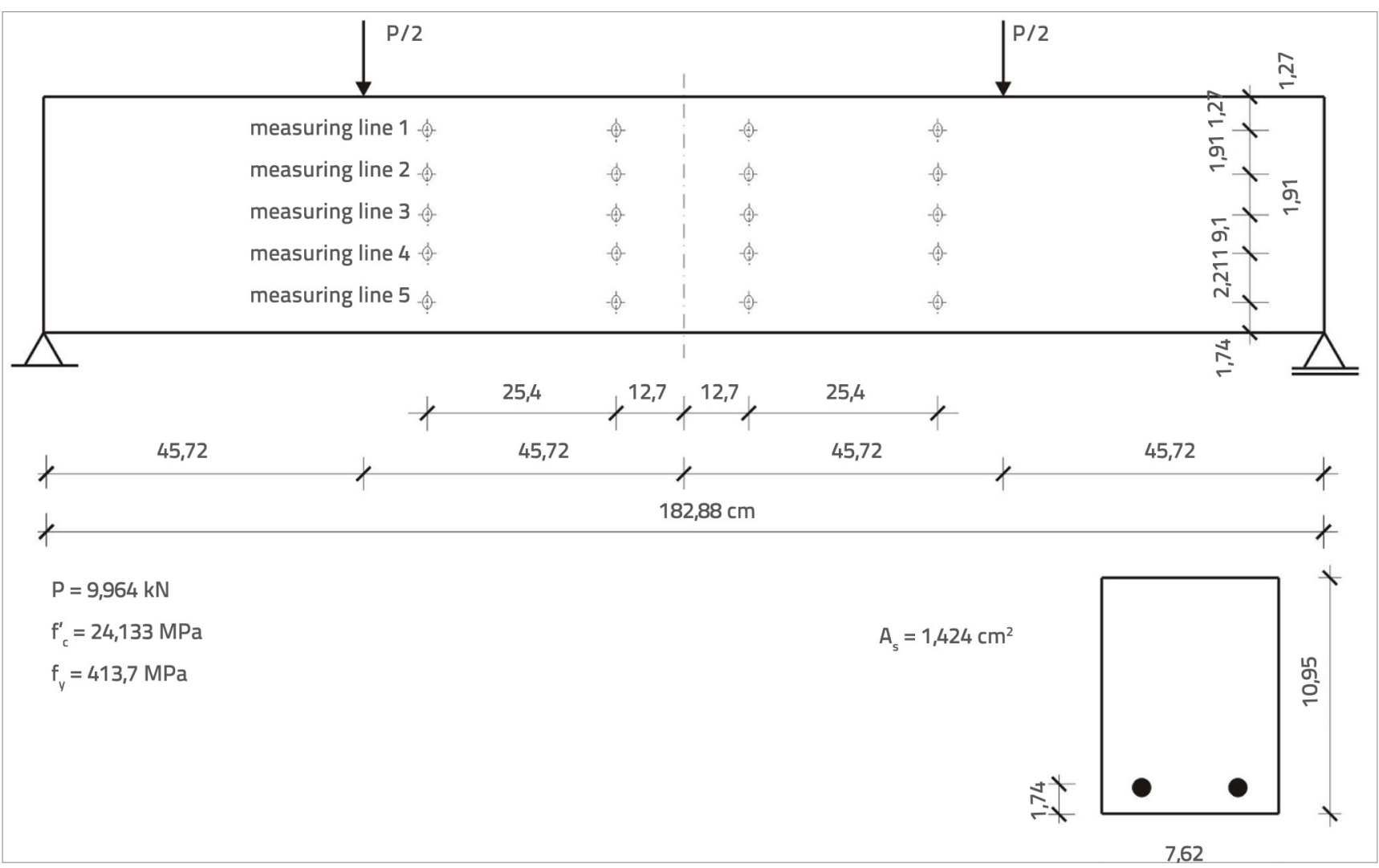

Figure 6. Geometry and beam load

Table 1. Long-term parameters

\begin{tabular}{|c|c|}
\hline Average element radius & $\mathrm{h}_{0}=44.0 \mathrm{~mm}$ \\
\hline Relative humidity & $\mathrm{RH}=50 \%$ \\
\hline Mean compressive strength at 28 days & $\mathrm{f}_{\mathrm{cm}}=24.133 \mathrm{MPa}$ \\
\hline Age of concrete at the time of loading & $\mathrm{t}_{0}=30$ dana \\
\hline
\end{tabular}

Beam displacements according to Corley and Sozen [17], and displacements obtained by this numerical model, are shown in Figure 7. A good correspondence of results was registered even at high levels of compressive stress. Cracks appear already at the load factor 0.3 , while the entire tensile zone of the beam is cracked at full load. Displacement values, particularly in case of beams with small percentage of reinforcement, are significantly influenced by the tensile strength of concrete. The tensile softening model describes the contribution of concrete in fractured areas in taking on the tensile stresses.

Beam deformation along its height in Gauss points of the element whose coordinate $x=0.7577 \mathrm{~m}$ is closest to measurement points with the coordinate $x=0.7874 \mathrm{~m}$, is shown in Figure 8. The deformation at the top and bottom edges of the beam can be obtained by extrapolation of
Table 2. Short-term material parameters

\begin{tabular}{|c|c|}
\hline Concrete & Rainforcement \\
\hline $\begin{array}{l}\text { Modulus of elasticity } \\
\mathrm{E}_{\mathrm{c}}=25000.0 \mathrm{MPa}\end{array}$ & $\begin{array}{l}\text { Modulus of elasticity } \\
E_{s}=20000.0 \mathrm{MPa}\end{array}$ \\
\hline $\begin{array}{l}\text { Poisson's coefficient } \\
v=0.166\end{array}$ & $\begin{array}{l}\text { Yield point } \\
\mathrm{f}_{\mathrm{y}}=413.7 \mathrm{MPa}\end{array}$ \\
\hline $\begin{array}{l}\text { Limit compressive strength } \\
\mathrm{f}_{\mathrm{c}^{\prime}}=24.133 \mathrm{MPa}\end{array}$ & $\begin{array}{l}\text { Hardening parameter } \\
\mathrm{H}=0\end{array}$ \\
\hline $\begin{array}{l}\text { Limit tensile strength } \\
\mathrm{f}_{\mathrm{t}}=2.0 \mathrm{MPa}\end{array}$ & $\begin{array}{l}\text { Limit strength } \\
\mathrm{f}_{\mathrm{s}}=620.6 \mathrm{MPa}\end{array}$ \\
\hline $\begin{array}{l}\text { Crushing deformation } \\
\varepsilon_{\mathrm{cu}}=0.0035\end{array}$ & $\begin{array}{l}\text { Relative limit deformation } \\
\varepsilon_{\mathrm{su}}=0.01\end{array}$ \\
\hline $\begin{array}{l}\text { Tensile stiffness parameters } \\
\varepsilon_{\mathrm{m}}=0.5 \\
\varepsilon_{\mathrm{ts}}=0.0012\end{array}$ & \\
\hline $\begin{array}{l}\text { Shear stiffness parameter } \\
\varepsilon_{\mathrm{sh}}=0.0012\end{array}$ & \\
\hline
\end{tabular}

measurement results. It is evident that deformations of the cross-section are not entirely straight, which can be explained by the relatively coarse finite element mesh, and by the effect of tensile creep in the region of tensile softening of concrete. 


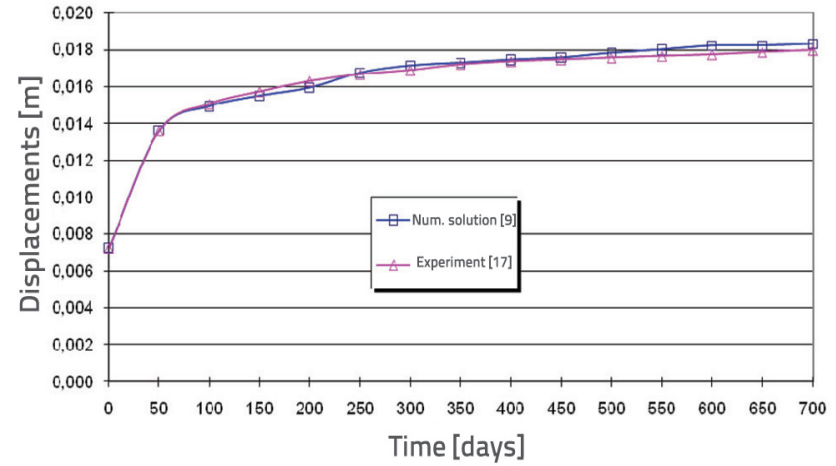

Figure 7. Middle of beam displacements over time

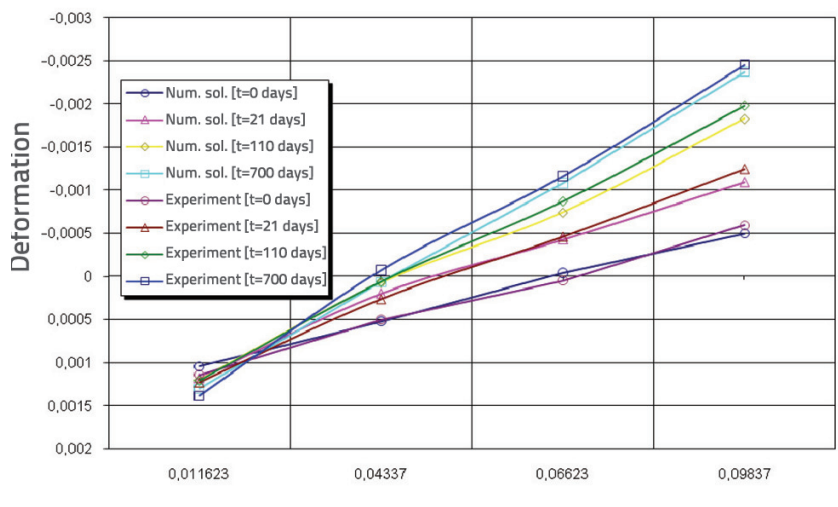

Beam height (G. P. koordinates) [m]

Figure 8. Axial deformations along the beam height

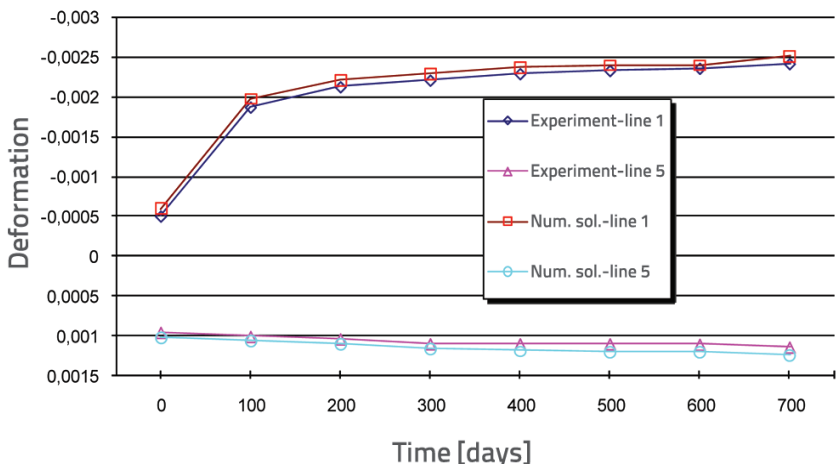

Figure 9. Beam deformations at measuring lines over time
Beam deformations for measurement lines at the intersection nearest to the middle of the beam are shown in Figure 9. Because of the simple finite element mesh, and hence the position of Gauss points along the beam height, the comparison of results is presented for measurement lines 1 and 5 only, because they are closest to the position of Gauss points along the beam height.

Figure 10. shows beam displacements due to self-weight, external load, creep, and shrinkage.

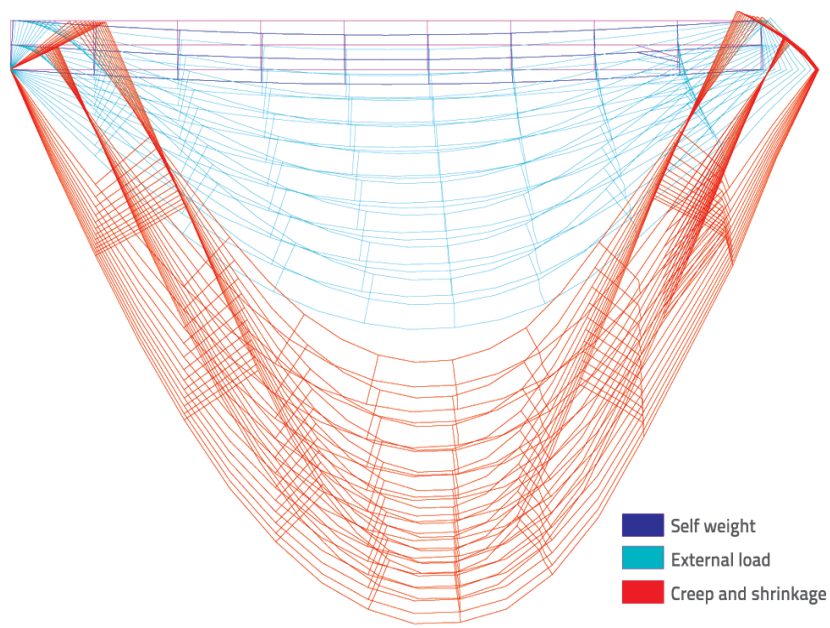

Figure 10. Beam displacements [m]x1000

\section{Example 2.}

A simple reinforced concrete beam, experimentally investigated by Jaccoud and Favre [18], is analyzed In this example. Five identical beams are examined at different load levels. This beam is also analyzed by the numerical creep model described in paper [19]. In this model, the beam is discretized with 12 finite shell elements. For the concrete tension, a simple linear viscoelastic model is used, until appearance of cracks in the concrete. It can be concluded from geometry and load that the aim is to evaluate the influence of creep of concrete at high levels of compressive stress, where the strong influence of nonlinearity of creep can be observed.

Figure 11. shows the geometry and load of beam, and in Table 3. material parameters are given. Beam is discretized with 24 eight-node finite elements.
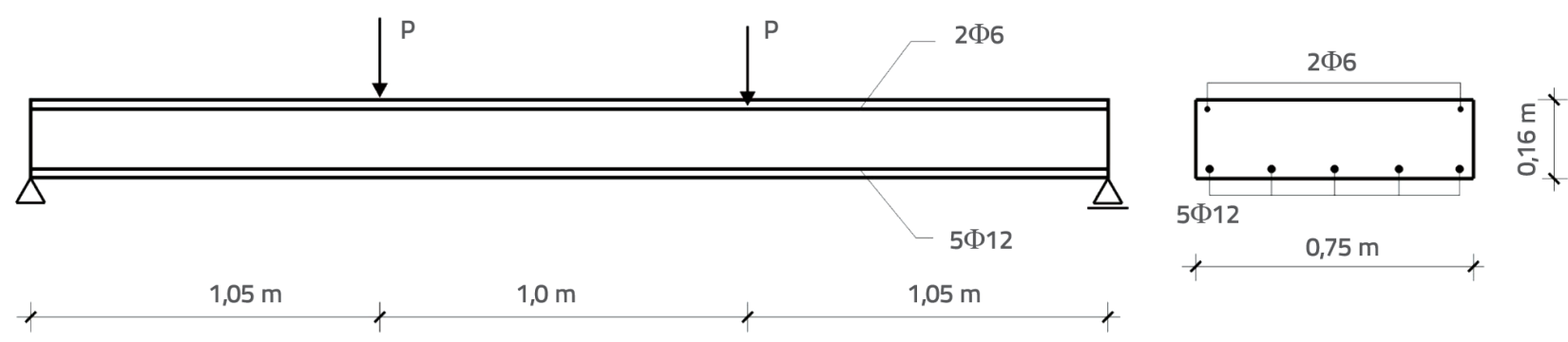

Figure 11. Geometry and beam load 
Table 3. Material parameters

\begin{tabular}{|l|l|}
\hline Concrete & Rainforcement \\
\hline $\begin{array}{l}\mathrm{f}_{c}=28.8 \mathrm{MN} / \mathrm{m}^{2} \\
\varepsilon_{\mathrm{u}}=0.0022\end{array}$ & $\mathrm{f}_{\mathrm{y}}=480.0 \mathrm{MN} / \mathrm{m}^{2}$ \\
\hline $\begin{array}{l}E_{c}=29300.0 \mathrm{MN} / \mathrm{m}^{2} \\
\mathrm{f}_{\mathrm{t}}=1.80 \mathrm{MN} / \mathrm{m}^{2}\end{array}$ & $\mathrm{E}_{\mathrm{s}}=185000.0 \mathrm{MN} / \mathrm{m}^{2}$ \\
\hline$v=0.15$ & $\varepsilon_{u}=0.01$ \\
\hline
\end{tabular}

Results obtained by experimental testing and numerical modelling are presented in Figure 12 for three levels of load $\mathrm{P} 03.15 \mathrm{kN}, \mathrm{P}=6.29 \mathrm{kN}$ and $\mathrm{P}=9.44 \mathrm{kN}$. A mid span beam displacement is monitored over time. It can be observed that this model provides very good results with respect to beam geometry due to its low height and a small number of finite elements over the height. The accuracy of results is certainly influenced by tensile creep, and the non-linearity of creep at high compressive stress levels.

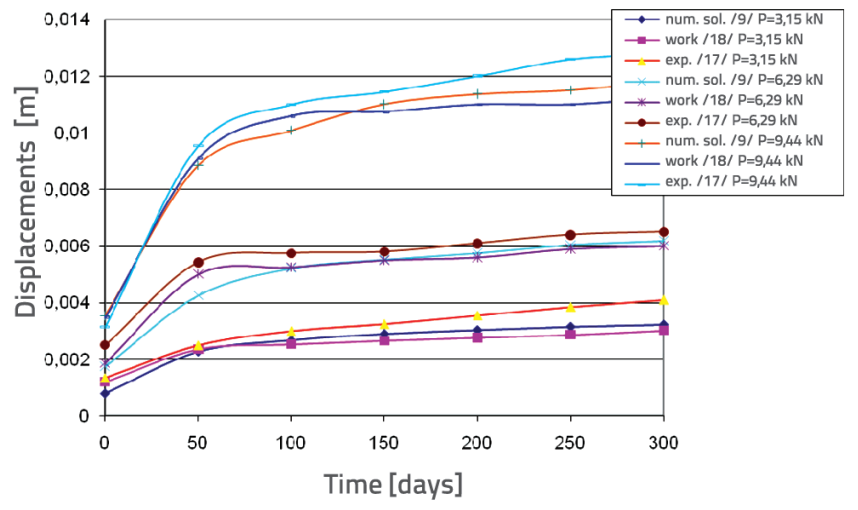

Figure 12. Middle of beam displacements over time

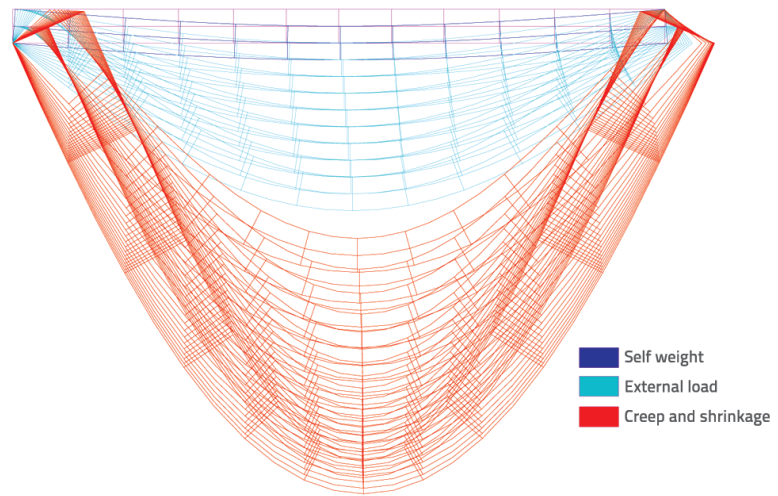

Figure 13. Beam displacements [m]x1000

\section{Example 3.}

The bridge in Capljina is analysed in this example [9]. The bridge is a frame structure with the spans measuring $40+84$ $+40 \mathrm{~m}$, and with hinge connections to adjacent supports. The bridge intrados is parabolic, and the height ranges from 192 $\mathrm{cm}$ to $404 \mathrm{~cm}$. The thickness of the upper slab is constant throughout the length of the bridge, and it is $20 \mathrm{~cm}$ at the cantilevered section, and $26 \mathrm{~cm}$ in the middle of the box girder. The lower slab is of variable thickness. The greatest thickness of this slab, amounting to $50 \mathrm{~cm}$, is at intermediate support positions. This thickness decreases linearly down to $18 \mathrm{~cm}$ in the middle of the large span, and at end support positions. The side walls of the box are also of variable thickness. The greatest thickness of these walls is $62 \mathrm{~cm}$ at intermediate support positions, while the smallest thickness of $24 \mathrm{~cm}$ has been measured at the end support positions, and in the middle of the large span. The bridge superstructure is made of concrete MB45. The prestressing system BBR CONA COMPACT is used, with tendons $12 \Phi 0.5^{\prime}$, and with the quality of $1660 / 1860 \mathrm{MPa}$. The initial prestressing force of each tendon is $1250 \mathrm{kN}$.

A half of the bridge's longitudinal section is shown in Figure 14. Typical cross-sections are given in Figure 15. The crosssection 10 is located on the right side of the left support of the great span. It contains the group B and group A tendons. Group $B$ tendons are located in the upper slab of the box, while group A tendons are located in box walls. The cross-section 19 is located in the middle of the great span. The bridge is not symmetrical because of different height of the corresponding section, and so the model of the entire bridge had to be prepared. The position of the group of tendons above the central pier of the bridge is shown in Figure 16, while the replacement cross-section, used in the numerical analysis, is shown in Figure 17.

The bridge structure is discretized with 996 8-node 2D finite elements, and the total of 3333 nodes. Prestressing tendons were discretised by projecting all tendons in the vertical plane. In this way, the group B tendons are presented with the total of two tendons, one above the middle of the leftside support, and the other in the middle of the right-side support. In addition, the group C tendons are represented with the total of three tendons, which are located in the lower box slab of each span. The group $A$ tendons are shown with the total of sixteen tendons, eight above both central supports. In this way, the total of 21 tendons was obtained, which discretization follows the discretization of basic structural elements of concrete.

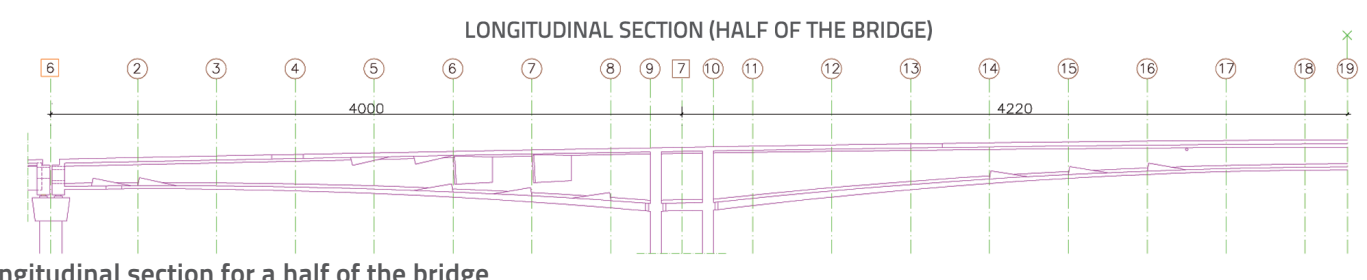

Figure 14. Longitudinal section for a half of the bridge 


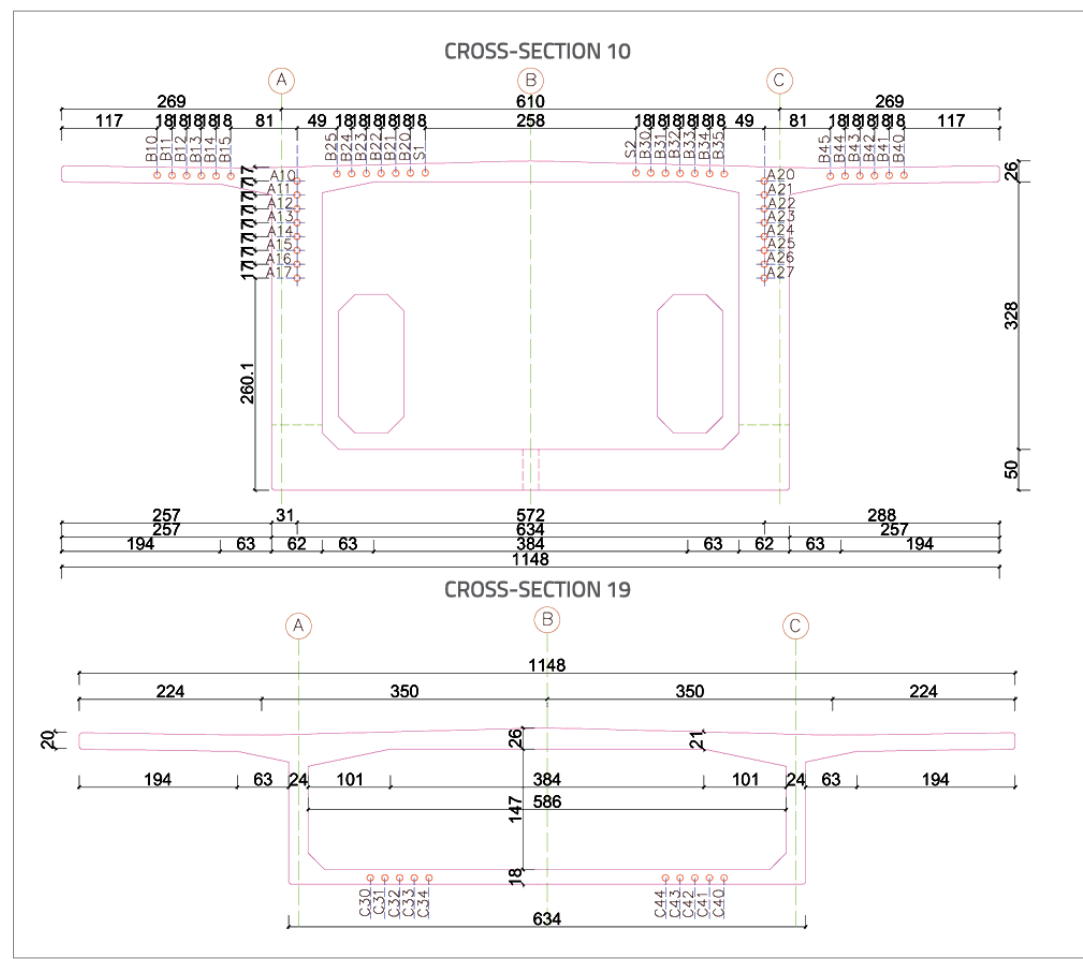

Figure 15. Typical cross-section
The load on the bridge, reduced to the plane through longitudinal axis of the bridge, amounts to $42 \mathrm{kN} / \mathrm{m}$. It contains the weight of water insulation, curbs, fence, installations, and asphalt.

Due to the size of the model, the traditional reinforcement RA400/500 was taken only in the lower and the upper box slab, the lower and the upper zone, and therefore 332 concrete elements include reinforcing elements.

Displacements of the central vertex of the arch were measured geodetically on four occasions. First time during the bridge load testing, and then after 80,140 , and 360 days.

Given the characteristics of this numerical model and actual structure, it can be said that its accuracy depends on the following facts:

- simplified geometry of the model as related to actual construction

- simplification in terms of the position of tendons and their projection into the corresponding resultant tendon, and in terms of modelling time for each prestressing tendon

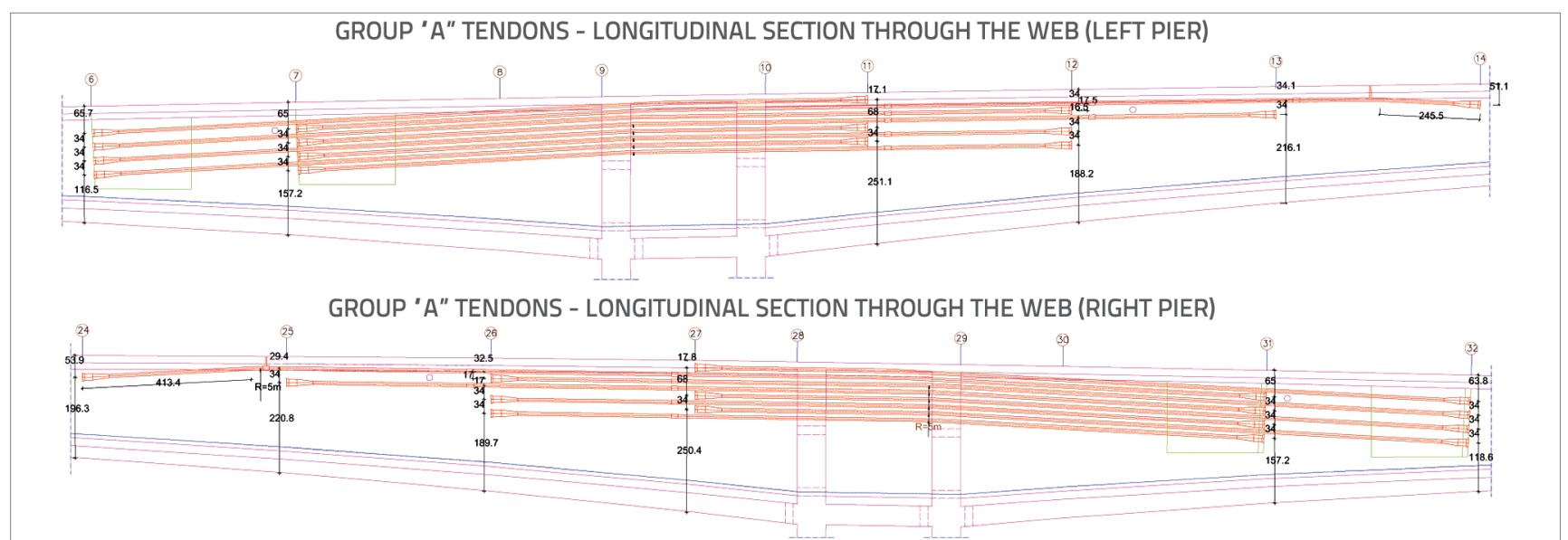

Figure 16. Tendon position above intermediate supports

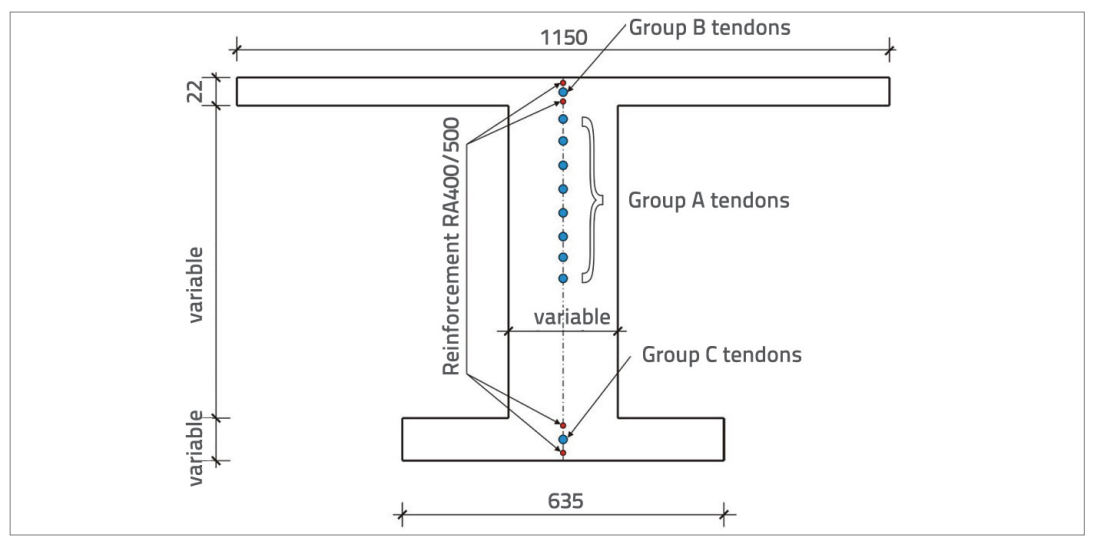

Figure 17. Replacement cross section
- impact of the reinforcement on the deformability of structure was not taken into account

- impact of volume and cross-sectional area, and the humidity of the environment on the value of creep and shrinkage deformations

- impact of the time of first loading, because the structure of the bridge was loaded with the remaining dead load until after the end of the last segment in the middle of the large span of the bridge was finished, which differs significantly from the numerical model. The segments, which were previously 


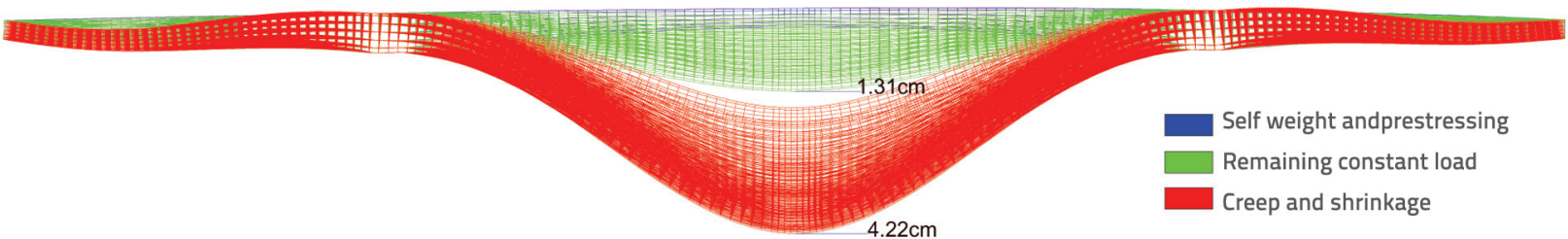

Figure 18. Bridge displacements over time

erected, already suffered a certain amount of creep and shrinkage deformations.

Displacements of the entire bridge after 360 days are shown in Figure 18. The displacement measured in the middle of the bridge, and displacements obtained by this numerical model without conventional reinforcement and with such reinforcement, are shown in Figure 19. The difference between the measured and actual displacement after one year amounts to about $8 \mathrm{~mm}$ in case without conventional reinforcement, and to no more than $4 \mathrm{~mm}$ in case with the traditional reinforcement in the upper and lower box slab. This points to a considerable influence of classical reinforcement on the deformability of prestressed structures, which obviously takes a part in the reduction of stresses and deformations.

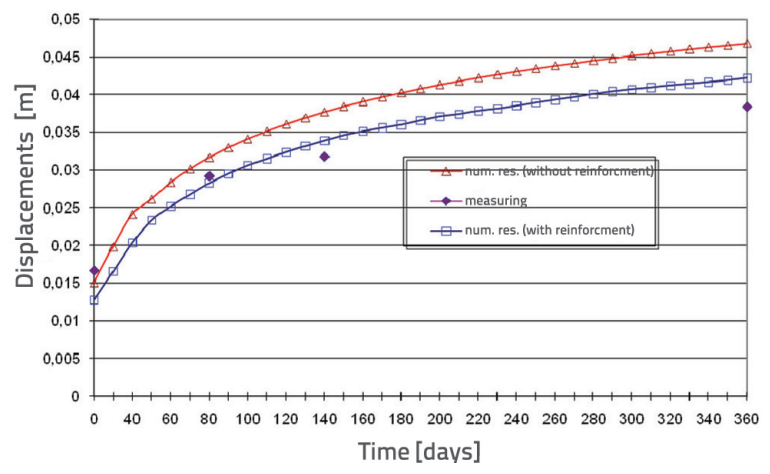

Figure 19. Middle of bridge displacements over time

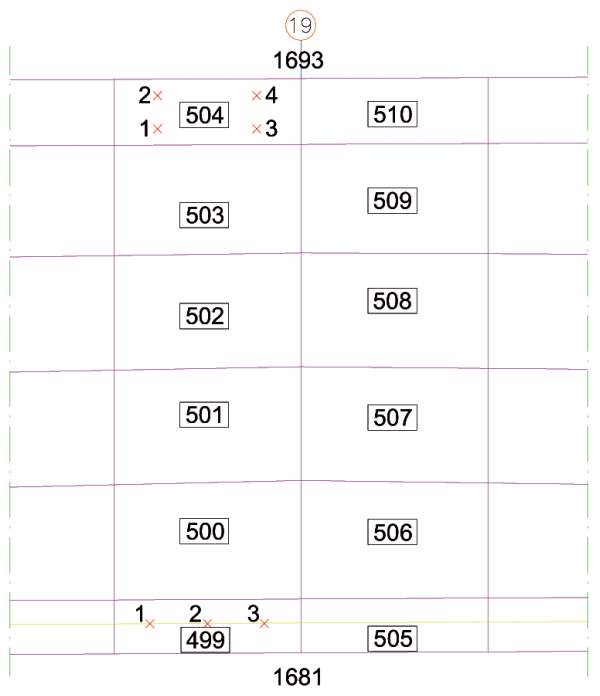

Figure 20. Middle of bridge finite element mesh
The finite element mesh in the middle of the bridge, with specified integration points of the concrete element 504 and the tendon element contained in concrete element 499, is shown in Figure 20. The change in concrete stress $\sigma_{x x}$ in the element 504 and the integration point 4, closest to the middle of the bridge, is shown in Figure 21. It is evident that concrete deformations decrease over time. The change in the tendon force in element 499, in the integration point 3, closest to the middle of the bridge, as obtained by numerical model, is shown in Figure 22. A very small increase in that force was registered. In fact, the increase amounted to about $1 \%$ at 250 days.

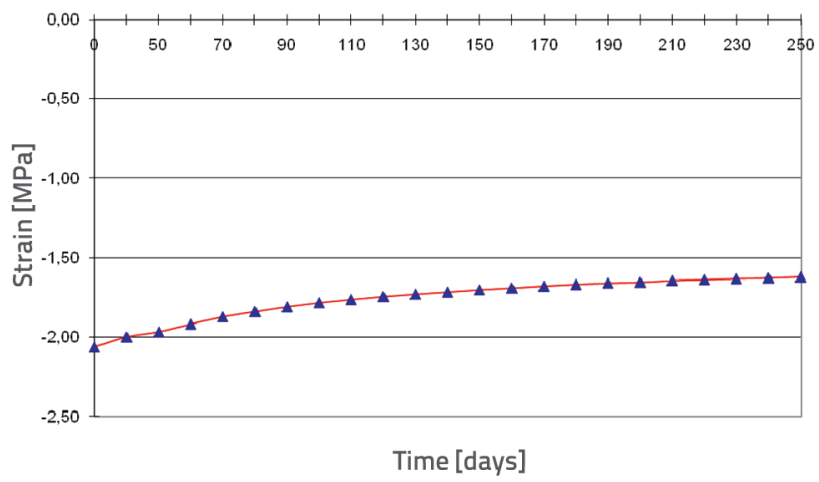

Figure 21. Stress $x-x$ in G. P. 2. of element 504

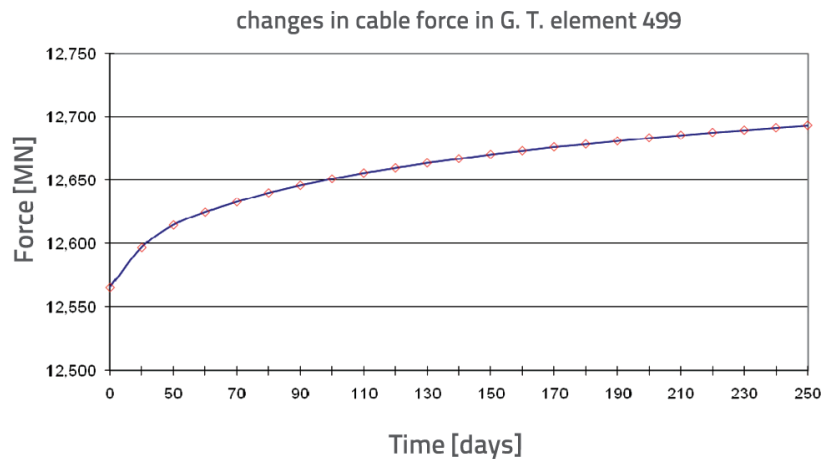

Figure 22. Cable force change

Despite the previously mentioned impact on the accuracy of the numerical model, it can be said that it provides good and expected results, considering the phenomenology of the problem it describes.

The adding of traditional longitudinal reinforcement in the upper and lower box slab has led to a decrease in 
displacement, both instant and time dependent, so that the difference between the measured and numerically obtained displacements amounts to less than $10 \%$ after one year. The adding of the remaining longitudinal reinforcement in the box walls, and of transverse reinforcement, would have further reduced this difference in displacement.

\section{Conclusions}

In this paper, the problem of time-dependent deformations of concrete is analysed, namely the creep and shrinkage, starting from the phenomenology of the problem and its impact on the reinforced concrete and prestressed concrete structures. A new numerical model for in-plane analysis of creep deformation of concrete is presented, based on the correction of its elastic modulus in the main directions, for the current state of principal stress.
It can be concluded from the results obtained in some examples that the developed model provides physically acceptable solutions, and possesses all the features of an efficient numerical procedure. Comparing the results of this model with reference solutions given in the literature, and the measurements performed in the field, it can be concluded that the model is primarily functional, but also rational in terms of its mathematical formulation. Although the specific analysis of the accuracy of the model was not performed, it can reasonably be stated that it affects the size of the time step, particularly at the beginning of the process, as well as the modelling of concrete subjected to uniaxial pressure. The selection of creep function and creep coefficient plays a significant role as well. It is therefore necessary to take smaller time steps (1-3 days) in the beginning, so as to be able to track more closely actual development of the concrete creep process.

\section{REFERENCES}

[1] The Adam Neville Symposium: Creep and Shrinkage - Structural Design Effects, SP-194, Eds. A. Al-Manaseer, ACl, 2000.

[2] Bazant, Z. P. \& Baweja, S.: Creep and shrinkage prediction model for analysis and design of concrete structures, model B3, Materials and Structures, 28(6), pp. 357-365, 1995.

[3] Selna, L. G.: Time Dependent Behaviour of Reinforced Concrete Structures, Report No. 67-Report No. 67-19, UC-SESM Division of Structural Engineering and Structural Mechanics, University of California, Berkeley, 1967.

[4] Neville, A. M, Dilger, W. H. \& Brooks J. J.: Creep of plain and structural concrete, Construction Press, London and New York, 1982.

[5] Ghali, A. \& Favre, R.: Concrete Structures: Stresses and Deformations, Chapman and Hall Ltd, New York, 1986.

[6] Nikolić, Ž.: Razvoj numeričkog modela za naknadno prednapinjanje armiranobetonskih konstrukcija u ravnini, magistarski rad, Građevinski fakultet Sveučilišta u Splitu, Split, 1993.

[7] Nikolić, Ž. \& Mihanović, A.: Non-linear finite element analysis of post-tensioned concrete structures, Engineering Computations, Vol. 14, No. 5, (1997), pp. 509-528, MCB University Press.

[8] Nikolić, Ž.: Numeričko modeliranje armiranobetonskih i prednapetih konstrukcija, Građevinar, Vol. 44, (1995), str. 121129.

[9] Kožul, M.: Numerička simulacija vremenski ovisnih deformacija betona, disertacija, Gradevinski fakultet Sveučilišta u Mostaru, Mostar, 2011.

[10] EUROCODE 2, ENV 206: Design of Concrete Structures, Part 1: General Rules and Rules for Buildings, Brussel, 1990.
[11] Damjanić, F. B.: Reinforced Concrete Failure Prediction Under both Static and Transient Conditions, Ph. D. Thesis, University of Wales, Swansea, 1983.

[12] Chen, W. F.: Plasticity in reinforced concrete, McGraw-Hill Book Company, New York, 1981.

[13] Hinton, E. \& Owen, D. R. J.: Finite Elements in Plasticity, Theory and Practice, Pineridge Press, Swansea, UK, 1980.

[14] Hofstetter, G. \& Mang, H. A.: Computational Mechanics of Reinforced Concrete Structures, Vieweg Verlag, Braunshweig/Wisbaden, 1995.

[15] Hognestad, E.: A study of Combined Bending and Axial Load in Reinforced Concrete Members, University of Illinois Eng. Exper. Station Bull. Ser. No. 399, Bull No. 1, 1951.

[16] Darwin, D. \& Pecknold, D. A.: Nonlinear biaxial stressstrain law for concrete, Journal of Engineering Mechanics Division, ASCE, 103(2) (1977), pp. 229-241.

[17] Corley, W. G. \& Sozen, M. A.: Time-Dependent Deflection of Reinforced Concrete Beams, ACl Journal, Vol. 63, (1966), No. 3, pp. 373-386

[18] Jaccoud, J. P. \& Favre, R.: Deflections of reinforced concrete structures: Experimental verification of a computing method, Technical report, ITBTP, 1982.

[19] Bockhold, J., Petryna, Y. S. \& Kratzig W.: Nonlinear basic creep of concrete members under high compressive stresses, European Congress on Computational Methods in Applied Sciences and Engineering, ECCOMAS 2004., Jyvaskyla, 24-28 July, 2004. 